\title{
Establishing The Total Quality of A Type Of Result Obtained By An Economic Company - Generalities
}

\author{
Nicolae Dobrițoiu \\ Assoc. Prof. Eng. Ph.D. \\ University of Petroșani, Romania \\ Universității Street 20, 332006, Petroșani, Romania
}

\begin{abstract}
The results of the activities carried out in an economic company are concretized in one or more types of products or services of a certain quality. The quality of products and services of an organization is determined by the ability to satisfy customers and the intended and unintentional impact on relevant stakeholders, or The quality of products and services not only includes their intended functions and performance but also the value and benefit perceived by the client (SR EN ISO 9000: 2015) According to these definitions, taken from the quality standard SR EN ISO 9000: 2015, it results that a product is of high quality when the following is achieved:

-satisfaction of a large number of consumer expectations;

-encourage consumers to meet new expectations;

-the cost of meeting these expectations should be as small as possible;

-the period in which a product meets the expectations must be as high as possible;

-the cost of using the product by consumers must be as small as possible.

Due to the fact that at the level of national economy there is a great variety of types of products and services it is necessary to group them according to various classification criteria. Also, each type of result obtained by a company is described by a variable number of quality characteristics, this leads to grouping these qualitative characteristics according to various classification criteria. In general, determining the quality of a type of result obtained by a firm requires knowledge of the group's name and the position it occupies in the resulting group according to an established classification criterion. Developing a mathematical model for determining the total quality for a type of result requires the knowledge of following information:

-name of result type;

-classification criteria after which the type of result is grouped;

-the name of the result type classification group and its position in the group;

-criteria for classifying qualitative characteristics;

-name of classification group and the position of the qualitative characteristic in the group.
\end{abstract}

\section{OVERVIEW}

At the multitude of meanings in connection with the concept of products quality it adds the fact that, as the products demand diversification increases and with the industrial production develops, the notion of products quality has evolved and diversified through the following terms:

- $\quad$ potential quality", meaning the quality of the product after design, before assimilation into the manufacturing process;

- "partial quality", representing the ratio between the quality obtained and the required quality;

- "achieved quality" is the quality resulting from the check at the end of production line;

- "assured quality" is the quality resulting from a unitary program comprising all quality control activities (prevention, measurement and corrective action);

- "total quality", this concept integrates the degree of utility, economy, aesthetics and ergonomics of products viewed from a functional and social point of view, etc. 
In order for a product to be demanded by consumers, it will have to satisfy a number of needs. The higher the number of needs and the cost of satisfaction is lower, the better quality the product.

A need may be fulfilled by one or more qualitative features.

Specialty literature highlights a large number of definitions of the quality concept, of which we present the most representative ones:

1. "Product quality" is the expression of the degree of social utility of the product, the extent to which, through its technical, functional, psychosensory characteristics and of economic parameters, it satisfies the needs for which it was created and respects the restrictions imposed by the general interests of society, regarding the social and economic efficiency, the protection of the natural and social environment.

2. The quality of products and services of an organization is determined by the ability to satisfy customers and the intended and unintentional impact on relevant stakeholders,

or

The quality of products and services not only includes their intended functions and performance but also the value and benefit perceived by the client (SR EN ISO 9000: 2015)

Starting from this definition, it is observed that the overall quality of a result is determined in several stages, namely:

- the stage I consists of establishing the partial quality of a product, made by a company, in the sales phase;

- the stage II consists in determining the partial quality of the result depending on how the product meets the needs for which it was purchased;

- the stage III consists in establishing the partial quality of the result, given by the availability;

- the stage IV, consists in determining the partial quality of the product, given by the costs of using the product by the beneficiary.

- the stage $\mathrm{V}$ consists in establishing the partial quality of the product, given by its removal and destruction.

- the stage VI, consists in establishing the partial quality depending on the product's environmental impact on the environment in which it operated.

For each of these types of quality, a coefficient of importance is assigned and the sum of these coefficients of importance is equal to 1 .

Determining the total quality of a result is done with the relation:

where:

$$
C^{T}={ }_{i=1}^{5} C_{i} * g_{i}
$$

$-\mathrm{C}_{\mathrm{i}}$ represents the value of the partial quality established in the "i" stage and is expressed in points, and the total number of points that a partial quality may take is: 100,1000 , or 10000 ;

- $g_{i}$ is the degree of importance of the established quality in stage " $i$ ".

Observation. By assigning a large number of points to the maximum value of the quality of a product obtained in a firm, at a certain stage of its existence it can better highlight its total quality. 
Some of the determined partial qualities may present dynamics at different times, and this may influence total quality.

In order to determine the total quality of a product it is necessary to achieve a classification of the products according to the degree of complexity.

At national level and in the European Union there are classifications of these results, namely:

- CAEN 2018 - Classification of activities in the national economy

- CPSA 2007 - Classification of products and services associated with activities

- CPSA is the acronym for the Classification of Products and Services adjacent to Activities and the CPSA code is a numeric symbol specific to a particular product or service. CPSA is the romanian version of the corresponding European classification CPA 2002 (EU standard) and CPC rev.3.1 (UN standard).

\section{THE QUALITY CHARACTERISTICS OF A PRODUCT}

The quality of a product is a cumulus of qualitative characteristics, where each qualitative characteristic has a measured or attributive value, a value within a specified range, and each qualitative characteristic fulfills individually or in association with other characteristics within the product, a function, a necessity or a well-defined utility.

Quality characteristics are those properties of the entities through which the degree of satisfaction of customer requirements is assessed at a given moment.

Also, the ISO 9000: 2015 standard defines the term of quality characteristic, as "the characteristic (property) inherent of an object (object, entity, article, anything perceptible or imaginable) concerning a requirement (need or expectation which is declared, generally implied or mandatory) ".

Note 1. "Inherent" means which exists in something, especially as a permanent feature;

Note 2. A feature attributed to an object (eg the price of an object) is not a feature related to the quality of the object.

Due to the large number of qualitative characteristics that a product has, it is necessary to classify them, and the literature indicates the following classification criteria for qualitative characteristics, presented in table no. 1: 


\begin{tabular}{|c|c|}
\hline The criterion & The characteristic \\
\hline \multirow{5}{*}{$\begin{array}{l}\text { Nature and the effect it shows in the } \\
\text { process of use }\end{array}$} & Technical characteristics \\
\hline & Psycho-sensory characteristics \\
\hline & Availability characteristics \\
\hline & Economic and technical-economic characteristics \\
\hline & Social-general characteristics \\
\hline \multirow{2}{*}{$\begin{array}{l}\text { The criterion of the importance of the } \\
\text { quality characteristics in assuring the } \\
\text { utility and functioning of the products }\end{array}$} & Basic characteristics \\
\hline & Secondary characteristics \\
\hline \multirow{3}{*}{$\begin{array}{l}\text { The economic destination and the the } \\
\text { character of using products in the } \\
\text { consumption process }\end{array}$} & Characteristics of the means of work \\
\hline & Characteristics of work objects \\
\hline & Features for objects of individual consumption \\
\hline \multirow{4}{*}{$\begin{array}{l}\text { Possibility to quantify the quality } \\
\text { characteristics }\end{array}$} & Directly measurable features \\
\hline & Indirectly measurable features \\
\hline & $\begin{array}{l}\text { Features objectively comparable with the } \\
\text { standard sample }\end{array}$ \\
\hline & $\begin{array}{l}\text { Features subjectively comparable with the } \\
\text { standard sample }\end{array}$ \\
\hline \multirow{2}{*}{ The mode of expression } & Quantifiable features \\
\hline & Attributive characteristics \\
\hline
\end{tabular}

\section{STAGES FOR DETERMINING THE TOTAL QUALITY}

As stated in paragraph 1 , the total quality is determined in stages. The order of the stages presents a logic in the establishment of the total quality, which leads to the continuous improvement of the information regarding the total quality of the product.

\section{At the first stage is determined the partial quality of the product at the stage of sale.}

The qualitative characteristics underlying the determination of the quality of the product at the stage of sale are those given by the criterion "according to the nature and effect that it presents in the process of use". Determining the partial quality at the stage of product purchase is done in several phases.

- in phase I, the indicators of the qualitative characteristics provided in the criterion "by the nature and the effect that they present in the process of use" are identified.

- in phase II we identify the value ranges in which the values of each indicator vary.

- in phase III it is checked by sampling, on the basis of previously developed control plans, whether the values of the indicators of the followed qualitative characteristics take values in the predetermined ranges.

- in phase IV, after processing the data obtained in the third phase, through different statistical methods, it can be determined whether or not the products are of the required quality.

2. At the stage II, is determined the partial quality on how the product meets the needs for which it was purchased. The purchased product is used for different purposes by the beneficiary, during the period of use it is checked whether the product satisfies the needs for which it was purchased and, for each necessity, in part, are determined the cost values with their satisfaction. Knowing the values of these indicators, are determined the values of the indices. As a basis of comparison in the determination of the values of the indices can be: the 
values of the technical and economic indicators provided in the technical documentation, values obtained by similar products made by other companies, values obtained by other beneficiaries etc.).

The values of the indices allow a comparison of the obtained results with those provided in the technical-economic documentation and, depending on them, the partial quality can be established at this stage.

Also, at this stage, the costs of operating the product under different working conditions are monitored during different time periods, thus allowing for the determination of unit costs for the realization of a unit of product or service.

3. At the stage III, a partial quality is determined which refers to the availability of the product during its useful life.

According to STAS 8174 / 3-1977, availability is "the ability of a system to perform its specific function at a given moment or in a period of time, considering the combined aspects of reliability, maintainability and maintenance."

The partial quality determined at this stage is based on the statistical indicators of the availability characteristics (reliability, maintenance and availability).

Indicators of availability characteristics may influence the quality of the product.

4. Stage IV. The partial quality determined at this stage is based on the values of the synthetic or complex (integral) indicators obtained in the process of using the product, under certain working conditions and a certain period of time.

In the first phase we determine the average values of the indicators of the economic characteristics achieved in the activity of the product functioning, and among the most significant indicators we mention: productivity; specific consumption of raw materials, materials, fuels, energy; specific consumption with workmanship etc.

Depending on the values of the determined indicators, the values of the indices of these economic characteristics are calculated. When calculating these indices, the following values are used as the values to be compared: planned values; values achieved in previous periods; values achieved of similar products in the same time periods; values achieved by other beneficiaries; the values provided in the technical and economic documentation of the product.

By comparing these indices with the ones planned, the partial quality of the product can be determined for the time period considered.

Observation. The partial quality determined at this stage shows a dynamic for the environmental conditions in which the product is working and different time periods.

5. At Stage V it is determined the partial quality of the product due to its decommissioning and destruction.

Indicators determined at this stage of product life refer to all the costs of performing the necessary activities at this stage of the product, among which: 
- the cost of preparing the removal of the product;

- losses due to non-fulfillment of the planned period of operation (amortization costs);

- loss of production due to non-performance of the period of operation;

- the moral wear and tear of the product; high moral wear and tear leads to large production losses compared to similar products but with a low degree of moral wear and tear.

6. Stage VI consists in determining the quality according to the influence of the product on the environment in which it operates.

This partial quality refers to the influences that the product has had on the environment, concretized by a system of indicators, namely:

- the degree of environmental pollution surrounding the atmosphere;

- influence of some types of radiation, of chemical, physical-mechanical factors resulting from the operation of the product on the environment, on the workforce and on the population in the area;

- the influence of the chemical factors that can occur during the operating period on the environment, on the labor force and on the population in the area;

- the influence of the physical and mechanical factors that can occur during the product's lifetime on the environment, on the workforce and on the population in the area.

There are situations when the influence on the environment, the operation, the use of a product, is quite aggressive or positive, during the period of operation or in the near future or further away.

\section{CONCLUSIONS AND PROPOSALS}

To determine the total quality of a product of high complexity, the following groups of information must be known:

-the multiplicity of all sets of environmental conditions in which the product will work;

-dynamics of the alternation of sets of environmental conditions;

-periods of time the product works for each set of environmental conditions.

The research to be carried out will focus on the development of models that will form the basis of establishing partial qualities, taking into account the above mentioned information groups.

The total quality of a complex product is a function of partial qualities.

From the practical point of view, the knowledge of the total quality of a complex product is valuable for the redesign, research or design of similar products.

For the beneficiary it is important to know the partial qualities provided in the technicaleconomic documentation that will be checked in practice.

The proposed model for determining the total quality of a product can be used for all types of products, regardless of their complexity.

For consumer products, the total quality is determined by certain partial qualities, since these types of products, in their existence, do not go through all the stages of the existence of a complex product. 


\section{References}

Baron, T., (coord.), Quality and Reliability, Tehnică Publishing House, Bucharest, 1988 (in Romanian)

Dobrițoiu, N., Quality Assessment for a Company, University "1 Decembrie 1918", Alba Iulia, Proceedings of the International Scientific Conference "Challenges of Contemporary Knowledge-Based economy", November 16-17, 2007

Dobrițoiu, N., Quality Assessment for a Company 2, Magazine of Management and Economic Engineering, Vol. 6/No. 4(25), 2007

Dobriţoiu, N., Research contract No. 534/10.05.2010 - Technical and economic analysis of operating systems used by EMC for their optimization in case of new technical, economic and social conditions, code CPV71241000-9, University of Petroșani, 2010 (in Romanian)

Dobrițoiu, N., Quality Assessment for a Company 3, Proceedings of the 18th WSEAS International Conference on Applied Mathematics (AMATH '13), Recent Advances in Applied and Theoretical Mathematics, Budapest, Hungary, Dec. 10-12, 2013, Published by WSEAS Press, pp. 256-267, ISBN: 978-960-474-351-3

Dobrițoiu, N., Radu, S.M., Mangu, I.S., Considerations on the Quality of Coal Production in the Coal-Mining Deposit Oltenia, Romania, 24th World Mining Congress PROCEEDINGS - MINERAL ECONOMICS / Brazilian Mining Association/Instituto Brasileiro de Mineração (Org). 1ed. - Rio de Janeiro: IBRAM, 2016, e-book, Available at: www.wmc2016.org.br and www.ibram.org.br, 35-46, ISBN: 978-85-61993-11-5 e-book

Drăgulănescu, M., Drăgulănescu, N., The Management of Services Quality, AGIR Publishing House, Bucharest, 2003 (in Romanian)

Dumitru Ceaușescu, Utilizarea statisticii matematice în chimia analitică, Editura Tehnică, București, 1982 (in Romanian)

Juran, M., The Quality of Products, Tehnică Publishing House, Bucharest, 1973 (in Romanian)

Rusu, C., (coordinator), Manual of Economic Engineering - The Foundations of the Management of Quality, Dacia Publishing House, Cluj-Napoca, 2002 (in Romanian)

Tovissi, L., Vodă, V., Metode statistice - aplicaţii în producţie. Ed. Ştiinţifică şi Enciclopedică, București, 1982 (in Romanian)

Vasilescu G., Mitran T., ş.a., Statistică, Editura Didactică şi Pedagogică, Bucureşti, 1980 (in Romanian) 